\title{
Institutional Culture and Job Satisfaction: A Comparative Study of Faculty from Public and Private Universities in Islamabad, Pakistan
}

\author{
Shumaila Raza, Assistant Program Officer, COMSATS University Islamabad, Pakistan, \\ shumailaraza57@gmail.com \\ Dr Saira Taj, Research and Evaluation Department, Institute of Education, Lahore College for Women \\ University, Jail road Lahore, Pakistan, drsairataj@gmail.com \\ *Dr. Shahzadi Seema , Dr. Shahzadi Seema, Lecturer, Department of Education, The University of Haripur, \\ Pakistan, shahzadiseema29@gmail.com
}

\begin{abstract}
This study provides a critical review of the relation between institutional culture and job satisfaction experienced by faculty members of both public and private universities of Islamabad. The sample of the study comprises of 241 faculty members, 186 from public sector universities and 55 from private sector universities of Islamabad, Pakistan. A Job Satisfaction Survey was administered to measure job satisfaction and institutional culture through standardized questionnaire by Cameron and Quinn (2000). An independent sample t-test was performed to obtain the difference between private and public university faculty on job satisfaction. Results reveal that Institutional culture is positively related to job satisfaction in both public and private sector universities Furthermore, there was no significant difference found between the job satisfaction and institutional culture of Private and Public University faculty. Recommendations have been made for university management to provide personal growth initiatives to the faculty through arranging workshops and conferences to promote institutional culture and job satisfaction.
\end{abstract}

Keywords: Institutional culture, Job satisfaction, Higher Education Institutions, Public and Private Sectors, Pakistan.

Received: 08.12.2020 $\quad$ Accepted: 13.01.2021 $\quad$ Published: 06.02.2021

\begin{abstract}
Introduction
Institutional culture is a significant factor in managing Institutional behavior. Management experts and authors have made deliberate, extensive efforts to define and identify its effect on the behavior of workers. According to Huczynski and Buchanan (2010), Institutional culture is considered a genuinely uniform arrangement of custom, values, beliefs, conventions, and strategies that are transmitted by workers of the Institution. The definition of Siefollahi and Davari (2008) is very useful to present the culture's combined nature and shows that culture exists in both levels of behavior and beliefs. Moreover, according to the Liao and Chuang (2007), institutional culture is a framework that defines the behavior of personnel, institutional values and specific intentions of that institution. It regulates a specific personality of the institution.

The institutional culture delivers mostly silent guidelines cooperation with others in the institution unwritten rules and mostly silent guidelines increase the strength of the social system (Quinn, Cameron, Degraff, $\&$ Thakor,2006). The attractive and organized environment will promote encouragement and motivation for enhancing employee's commitment towards their career (Naderi Anari, 2012).

Transformation of production without highly qualified workers is not sufficient to achieve productivity growth. It is expressed that for working in high technology products, the increase in graduating a number of higher education is mandatory. It is the indicator of merging between the comprehension of the division of 'wellbeing' concept and sector 'desirable' for structural and economic growth (Sipilova, 2015).

Educational institutions are required to recruit educators who have high passionate insight since they may have a positive effect to upgrade education (Naderi Anari, 2012). According to Karabayik and Korumaz (2014), self-efficacy of a teacher at a higher level is related indirectly to life satisfaction and satisfaction in the workplace. Self-efficacy is a legitimate point to culture assorted setting. There is a positive relationship between the self-efficacy and fulfillment in the work environment.
\end{abstract}

Lyon and Ivancevich (2000) described job satisfaction as up to what extent an employee is satisfied or dissatisfied with three characteristics of the job, i.e. self-actualization, autonomy, and esteem means "how 
much is there now"., Bhuian and Menguc (2002) came up with the new definition of Job satisfaction, as per them, it is the extent to that someone judges the positive or negative aspects about the intrinsic or extrinsic characteristics of his/her job. They claimed that intrinsic job satisfaction refers to the work itself, while extrinsic job satisfaction refers to external factors affecting the work itself.

The subsequent studies conducted by (Lund, 2003), Gunlu et al., (2010), (Rao, 2005, Buitenbach and De-Witt (2005), (Sekaran, 1989), (Egan, Yang and Bartlett, 2004; Silverthorne, 2004), Kreis and Brockopp (1986), Yang and Hwang (2014); (1985 Spector) have also tested and verified various aspects of intrinsic and extrinsic job satisfaction.

(Locke \& Latham, 2002) stated that for an institution and its researcher, employment fulfillment is one of the best issues; numerous investigations of research have been made on various measurements of occupation fulfillment as it has been barely associated with marvels of association, for example, inspiration, execution, resolve, initiative and so forth. Many of the researchers have determined a group of predictors for job satisfaction, that include work, promotion, supervision, pay, co-workers and working environment (Sokoya,2000). (Decenzo \& Robbins, 1998; p.152) exposed that the aspects which affect the employees' job satisfaction are: environment, co-workers, and pay work. In other direction (Ellickson \& Logsdon, 2001) exposed that the required resources, a justifiable workload, passable equipment, and training prospects all affect job satisfaction of faculty. The greater part of analyst's measure the activity fulfillment on the establishment of employee's: pay, supervision, state of mind to the activity, promotion, support, firm policy and relations with colleagues (DeVane \& Chen, 2003).

In a university of Turkey, the job satisfaction of academics measured by the Kusku (2003) with the seven aspects management satisfaction, general satisfaction, colleagues, other group satisfaction, salary satisfaction, and work atmosphere. (Chen et al., 2006) dignified the job satisfaction of faculty in the private university of China through six satisfaction determining factors that is institution vision, pay, management system, respect, benefits, work atmosphere, feedback, and encouragement. Ssesanga \& Garrett (2005) dignified the academician's job satisfaction between the universities of Uganda with nine common features of their work involving teaching, governance, research, working environment, remuneration, supervision, opportunities for promotion, the behavior of co-workers and overall job terms and conditions. According to the Luthans (2005: p.212) the supervision, promotion, fellow workers, pay and work are the central factors of job satisfaction. Employees not only need excellent technical preparation; they also need sufficient skills to adapt to the changing requirements of the job (Ahmad, Karim, Din, \& Albakri, 2013; Carnevale \& Smith, 2013).

Every institution regardless of sector and region has a culture of its own. In public sector universities, there are some encouraging incentives in the form of salaries, up-gradation and job security. On the other hand, private teachers have some other rewards in the form of higher salaries, good working, and challenging environment. Different factors that can influence the performance of faculty like working environment, pay, contingent reward, relationship with co-workers, supervision, nature of the job and promotion. The Satisfaction level of faculty is different between public and private sector university that improves the performance of the teacher (Ayub, 2010).

Universities in the private sector provide various benefits to their teachers, for example, a satisfactory working environment, promotions, competitive pay packages as compared to the public sector universities (Volkwein \& Parmley, 2000).

There is a significant difference between the available equipment in the education department of the private and public sector universities located in the federal capital of Pakistan. Utilization and supply of resources of private sector universities are better than the public universities (Yasmeen et al., 2015).

Yang and Hwang (2014) portrayed job satisfaction from equity potential point of view in the way, that if an individual compares his/her own experiences with the rewards paid to him/her from the employer and finds that the outcomes are coherent, then he/she will undergo satisfied with his/her job. The literature review reveals that the relationship between institutional culture and job satisfaction in the context of public and private sector Universities is yet to be explored, due to the fact we have built the hypotheses for institutional culture and job satisfaction in the regional context. 


\section{Methodology}

The study was descriptive in nature; the survey method was used to collect data. This research focuses to compare the institutional culture of public and private sector universities and to determine the impact of Institutional culture being an independent variable on job satisfaction (dependent variable) of faculty working in public and private universities in Islamabad. The population comprised of all federally Chartered Universities and faculty members working under the faculty of management sciences and social sciences of public and private institutes in Islamabad. As per the criteria shared by HEC Pakistan, there are 14 public and 5 private Universities in Islamabad. The sample of the study was selected randomly, comprises of total 241 faculty members out of which, 186 from public sector universities and 55 from private sector universities. An adapted open-ended questionnaire was used to collect data from the respondents (Faculty members of public and private sector universities). The items of the questionnaire were measured on a five-point Likert scale. The collected data were tabulated, analyzed statistically by percentage, mean scores and t-test using statistical package for social science (SPSS).

\section{Results and Discussion}

Table 1: Job Satisfaction Comparison between Public and Private Universities

\begin{tabular}{|c|c|c|c|c|c|c|}
\hline \multirow{2}{*}{ S.No } & \multirow{2}{*}{ Indicator } & \multicolumn{2}{|c|}{ Public University } & \multicolumn{2}{|c|}{ Private University } & \multirow{2}{*}{ Results } \\
\hline & & Mean & St.Dev & Mean & St.Dev & \\
\hline 1 & $\begin{array}{l}\text { Work environment } \\
\text { of the university }\end{array}$ & 3.4852 & .76810 & 3.5045 & .77652 & $\begin{array}{l}\text { Different but } \\
\text { not significant }\end{array}$ \\
\hline 2 & Reward system & 3.2923 & .89252 & 3.3136 & .87760 & $\begin{array}{l}\text { Different but } \\
\text { not significant }\end{array}$ \\
\hline \multirow[t]{2}{*}{3} & $\begin{array}{l}\text { Co-worker } \\
\text { relationship }\end{array}$ & 3.6452 & .81442 & 3.6773 & .81177 & Same \\
\hline & Total & 3.4742 & 0.7391 & 3.4985 & 0.7393 & $\begin{array}{c}\text { Different but } \\
\text { no significan } \\
\text { difference }\end{array}$ \\
\hline
\end{tabular}

Table 1 contains the mean values of the three dimensions of job satisfaction in public and private sector universities are $3.48,3.29,3.64$ and 3.50, 3.31,3.67. Which authenticates the primary response of respondents relating to selected dimensions of job satisfaction towards "agreed" at 4th point of Likert scale. While standard deviation of from means of observations in public and private sector universities are .76, .89, .81 and $.77, .87$.

The mean values of the three dimensions of job satisfaction in management sciences and social sciences are $3.49,3.31,3.65$ and $3.48,3.27,3.64$. Which authenticates the primary response of respondents relating to selected dimensions of job satisfaction towards "agreed" at 4th point of Likert scale. While standard deviation of from means of observations in management sciences and social sciences are $.81, .84, .86$ and .71, .94, .75 respectively.

Table 2: Institutional Culture Comparison between Public and Private Universities

\begin{tabular}{|c|c|c|c|c|c|c|}
\hline \multirow[t]{2}{*}{ S.No } & \multirow[t]{2}{*}{ Indicator } & \multicolumn{2}{|c|}{ Public University } & \multicolumn{2}{|c|}{ Private University } & \multirow[t]{2}{*}{ Results } \\
\hline & & Mean & St.Dev & Mean & St.Dev & \\
\hline 1 & Dominant Characteristics & 3.4875 & .94065 & 3.4818 & .91550 & Same \\
\hline 2 & $\begin{array}{l}\text { Institutional Leadership \& } \\
\text { Management }\end{array}$ & 3.6523 & .93647 & 3.5818 & .85999 & $\begin{array}{l}\text { Different but } \\
\text { not significant }\end{array}$ \\
\hline
\end{tabular}




\begin{tabular}{|c|c|c|c|c|c|}
\hline Management Styles & 3.9001 & .83638 & 3.0321 & .72424 & $\begin{array}{c}\text { Different but } \\
\text { not significant }\end{array}$ \\
\hline Institutional Glue & 3.4416 & .82176 & 3.4234 & 80997 & Same \\
\hline Strategic Emphases & 3.4825 & .96669 & 3.5091 & .92792 & $\begin{array}{c}\text { Different but } \\
\text { not significant }\end{array}$ \\
\hline $\begin{array}{l}\text { Institutional Values \& } \\
\text { Practices }\end{array}$ & 3.5600 & 66901 & 3.5424 & .62544 & Same \\
\hline Communication & 3.3190 & .82933 & 3.3424 & .82615 & Same \\
\hline Motivation & 3.2673 & .92591 & 3.9001 & .88149 & $\begin{array}{c}\text { Different but } \\
\text { not significant }\end{array}$ \\
\hline Total & 3.4976 & 0.7701 & 3.4928 & 0.7248 & $\begin{array}{c}\text { No significant } \\
\text { difference }\end{array}$ \\
\hline
\end{tabular}

Table 2 indicates the mean values against eight dimensions of institutional culture of public and private universities located in Islamabad are 3.48, 3.65, 3.90, 3.44, 3.48, 3.56, 3.31, 3.26 and 3.48, 3.58, 3.03, $3.42,3.50,3.54,3.34,3.90$. Which verifies the primary response of respondents pertaining to selected dimensions of institutional culture of universities is going towards "agreed" at 4th point of Likert scale. While the standard deviation of observations from their means is $.94065,93647, .83638, .82176, .96669, .66901$, $.82933, .92591$ and $.91550, .85999, .72424, .80997, .92792, .62544, .82615, .8814$ respectively.

\section{Inferential Statistics}

\section{Independent Sample T-Test}

Hypothesis 1: There is no significant difference between the institutional culture of public and private universities.

The significance level of the mean difference between two groups one of the demographic variables i.e. public-sector universities and private-sector universities is measured by using the independent sample t-test for this study pertaining to dependent variable i.e. job satisfaction and independent variable i.e. institutional culture in the academic sector.

Table 3: Level of Job Satisfaction and Institutional Culture in Universities between Public Sector and Private Sector Respondents ( $=241)$

\begin{tabular}{|c|c|c|c|c|c|c|}
\hline Variables & $\begin{array}{c}\text { University } \\
\text { Type }\end{array}$ & $\mathbf{N}$ & Mean & $\begin{array}{c}\text { Std. } \\
\text { Deviation }\end{array}$ & F-value & P-value \\
\hline \multirow{2}{*}{ Job Satisfaction } & Public & 186 & 3.4742 & 0.7391 & 0.346 & .56 \\
\cline { 2 - 7 } & Private & 55 & 3.4985 & 0.7393 & & \\
\hline $\begin{array}{c}\text { Institutional } \\
\text { Culture in } \\
\text { Universities }\end{array}$ & Public & 186 & 3.4976 & 0.7701 & .466 & .50 \\
\cline { 2 - 7 } & Private & 55 & 3.4928 & 0.7248 & & \\
\hline
\end{tabular}

Table 3 describes the results of the independent sample t-test of job satisfaction; the mean values of public sector universities stands at 3.4742, which is slightly less than mean values of private sector universities i.e. 3.4985. Moreover, the F-values and p-values are $0.466<3$ and $0.50>0.05$ respectively which shows the insignificant difference between means of both public sector and private sector universities with regard to the institutional culture among universities because F-value is critically lower from its threshold value i.e. 3 and P-value is greatly higher from the threshold value i.e. 0.05. Therefore, the results indicate that there is no meaningful difference between both sector universities relating to institutional culture. 
So, hypothesis- 1 accepted which implies there is no significant difference in the institutional culture of public and private universities.

\section{Data Analysis}

This study has dully evaluated the demographic features of the respondents for detailed knowledge of the reader. The second hypothesis pertaining to examine the influence of institutional culture on satisfaction level among faculty is tested through regression coefficients by path analysis in AMOS.

Hypothesis 2: There is no impact of institutional culture on job satisfaction of faculty in public and private universities.

\section{Impact of Institutional Culture (IV) on Job Satisfaction (DV)}

The relationship between the institutional culture of public and private universities on Job Satisfaction is assessed by using Structural Equation Modelling (SEM) with an aim to test the proposed Hypothesis 2. Figure 4.1 is taken out by running the full model in AMOS.

Figure 4: SEM: Institutional Culture (IV) and Job Satisfaction (DV)

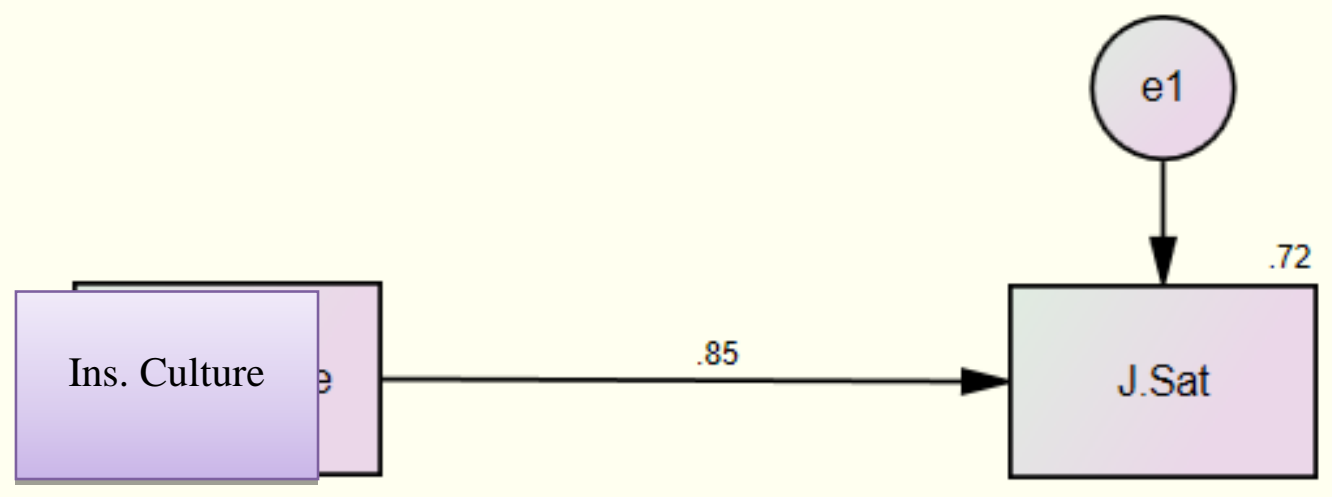

Figure 4.1 shows the standardized regression estimate between the institutional culture (independent variable) and Job Satisfaction (dependent variable). The result regarding acceptance or rejection of the hypothesis- 2 is briefed in table 4.35 to investigate the impact of the exogenous variable on an endogenous variable.

Table 4: SEM: Institutional Culture and Job Satisfaction (IV with DV)

\begin{tabular}{|c|c|c|c|}
\hline Variables & Estimate & P-Value & Hypothesis Support \\
\hline I. Culture $\rightarrow$ J.Sat & 0.85 & .85 & Hypothesis 2 is not accepted \\
\hline
\end{tabular}

Since the result of Table 4 contains the established relationship between institutional culture and satisfaction level of the faculty at their workplace and found positive and significant. The result shows 0.85 standardized regression weight

at a p-value $\leq 0.05$, which infers that if the level of institutional culture increases by one-unit among the faculty of both public and private universities, at that moment satisfaction level among faculty will increase by $85 \%$. 
Therefore, the result represents the rejection of hypothesis- 2 at a significance level of p-value $<0.05$ as proposed for this study.

\section{Discussion}

Findings of hypothesis1: There is no significant difference in the institutional culture of public and private universities indicates that there is no meaningful difference of institutional culture between public and private sector universities in Islamabad as proved by previous researches (Yasmeen et al., 2015)( Brewer \& Lam, 2009) (Rashid ,Sadia ,Rashid \& Uzma,2012)(Gabris \& Simo,1995) (Khan, Aajiz \& Ali ,2018). Yasmeen et al., (2015) found that there are no meaningful differences in the use of information technology and in the teachers training and skills in public and private universities of Rawalpindi and Islamabad. Gabris and Simo, 1995 indicated that there are no significant differences for 20 motivational needs, including the need for monetary rewards. According to Khan, Aajiz and Ali, 2018 there was no meaningful difference regarding knowledge management measurement between public and private universities. Rashid, Sadia, Rashid and Uzma, 2012 found no significant difference between the motivation of public and private sector with respect to Job contents. Din, Khan, Rehman and Bibi, 2011 resulted that there is no significant difference in the conflict management strategies of both public and private sector universities of Khyber Pakhtunkhwa. The result corroborated of (Brewer \& Lam, 2009).

The hypothesis 2:There is no impact of institutional culture on job satisfaction of faculty in public and private universities of this study is not accepted and proved that there is a significant impact of institutional culture on job satisfaction of faculty in public and private universities resembles with the results already presented by previous research undertaken by (Danish, Draz \& Ali, 2015) (Akram, 2013) (Shurbagi \& Zahari, 2012) (Erdem, 2014) (Pasebani, Mohammadi \&Yektatyar, 2012) (Gull \& Azam, 2012). There are many studies worked on job satisfaction with the individual characteristics of institutional culture and identify the positive relation with positive climate and job satisfaction, this hypotheses tested by Huang and Chuang (2007) in this study researcher conclude that at workplace learning increase the job satisfaction of personnel. Naderi Anari, 2012 indicates that an attractive and organized environment will promote encouragement and motivation for enhancing their commitment towards their career. Chiva and Alegre, (2008) indicate that institutional learning by a process of work develops the employee competency and job satisfaction. With respect to the full scope of institutional culture, several studies indicate that a positive relationship exists between them, Chang \& Lee, 2007 found that the institutional learning culture with job satisfaction showed a positive relationship.

\section{Conclusion}

The conclusions were drawn after the interpretation of data collected from the faculty of public and private sector universities in Islamabad.

\section{Conclusion Drawn from Faculty Responses of Close-ended Questions}

The objectives of the study were to compare the institutional culture in public and private sector universities. Furthermore, the effects of institutional culture on job satisfaction of faculty working in public and private sector universities. . For data analysis, Descriptive statistics and Structural Equation Modelling (SEM) were used to analyze the results of both variables (institutional culture and job satisfaction). To determine the significant relationship between the variables, the Independent Sample t-test and ANOVA were used.

1. Mean differences between public and private sector universities pertaining to institutional culture are calculated by using the inferential statistical tool independent sample t-test. The result of Hypothesis: 1 indicates that there is no significant difference in the institutional culture of public and private universities, which is accepted at the insignificance level of p-value $>0.05$.

2. For this study, the sample t-test of job satisfaction indicates that the mean values of public sector universities are slightly less than the mean values of private sector universities. This indicates that the faculty of Private Sector University is more satisfied regarding their job as compared to the faculty of public sector universities. Therefore job satisfaction level of public sector faculty can be enhanced.

3. The mean value of public and private sector universities regarding institutional culture 3.4976 and 3.4928 indicate that the primary response of faculty members pertaining to selected dimensions of an institutional culture of universities is going towards "agreed" at 4th point of Likert scale. Therefore a large number of faculty members are satisfied with the institutional culture of their universities. 
4. The result of Hypothesis: 2 presents that institutional culture has positive impact on Job Satisfaction in both public and private sector universities at $\mathrm{p}$-value .85 shows 0.85 standardized regressions weight at p-value $\leq 0.05$, which infers that if the level of institutional culture increases by one-unit among the faculty of both public and private universities, at that moment satisfaction level among faculty will increase by $85 \%$. Therefore, job satisfaction of faculty of public and private sector universities can be enhanced by promoting the level of institutional culture in the universities.

\section{Conclusion Drawn from Open-ended Questions}

Following conclusions were drawn after the interpretation of data collected from faculty is given below:-

\section{Private Sector}

Following conclusions were drawn after the interpretation of data collected from the faculty of private sector universities in Islamabad:-

1. Faculty of Private Sector University emphasizes that regular faculty training program and coaching sessions enhance job satisfaction.

2. Faculty agreed that research opportunities and self-respect improve the level of job satisfaction.

3. The faculty has confidence in the fact that institutional culture can be promoted by improving Interdepartment cooperation.

4. Faculty of private sector universities encourages valuing and respecting the ideas of students.

5. Faculty recommends the management to improve its behavior towards students. Relying on the fact that; performance of the students is enhanced when they feel more valued.

6. Faculty of Private Sector University also emphasizes on steps taken by the government of Pakistan providing fair salaries and other allowances like house rent, advance increments on higher qualification and conveyance allowance for the faculty.

\section{Public Sector}

Following conclusions were drawn after the interpretation of data collected from the faculty of public sector universities in Islamabad:-

1. Most of the faculty members of Public Sector University believe that job satisfaction level can be improved by promoting the interactive, healthy, peaceful, and conducive environment.

2. Faculty members feel that Job satisfaction level can be improved by promoting loyalty, sincerity, interaction, dedication and honesty for work and job.

3. The faculty believes that their job satisfaction level can be improved by providing them equal opportunities for career and allowances.

4. Faculty members agreed that autonomy to teach can improve their satisfaction level.

5. Faculty thinks that institutional culture can be improved by taking merit-based decision and participation of faculty in decision making.

6. The faculty believes that institutional culture can be promoted by managing interdepartmental meetings and functions.

7. Faculty suggests that the institution may take steps in order to enhance the communication and cooperation among the departments.

8. Faculty feels that institutional culture can be improved by encouraging equality, truth and effective examination and norms.

9. Like faculty of private sector universities, they also encourage student participation in different activities as these are useful and practical for students as well as faculty.

\section{Recommendations}

As the results have shown that institutional culture has a positive and significant impact on job satisfaction of faculty job in public and private sector universities. Based on such above conclusions of this study, some 
recommendations have been submitted with an aim to promote institutional culture and enhance the job satisfaction level of the faculty in both sector universities.

1. University management may provide personal growth initiatives and arrange workshops and conferences to promote institutional culture and to enhance the learning and job satisfaction of faculty in public and private sector universities.

2. Equal opportunities for training and promotion of the faculty members by the management might be provided.

3. Job satisfaction level of faculty in both sectors may be improved by encouraging equality, truth and effective examination.

4. Management of private sector universities may improve inter-department cooperation and relationships.

\section{References}

Ahmad, M., Karim, A. A., Din, R., \& Albakri, I. S. M. A. (2013). Assessing ICT competencies among postgraduate students based on the 21st century ICT competency model. Asian Social Science, 9(16), 32.

Ayub, N. (2010). A Comparative Study of Private and Public Universities Teachers Job Satisfaction. Alternative Perspectives in the Humanities and the Social Sciences, 86.

Bhatti, A., Pathan, H., Tabieh, A., \& Hassan, A., (2020). Impact of Learner-learner Rapport on L2 Learning: A Study of Public Sector Universities in Sindh, Pakistan. The Asian EFL Journal,27 (4.6), 204-226.

Bhuian, S. N., \&Menguc, B. (2002). An Extension and Evaluation of Job Characteristics, Organizational Commitment and Job Satisfaction in an Expatriate, Guest Worker, Sale Setting. The Journal of Personal Selling and Sales Management, 1-11.

Brewer, B., \& Lam, G. K. (2009). Conflict handling preferences: A public-private comparison. Public Personnel Management, 38(3), 1-14.

Buitenbach,J.H\& De-Witt,H.(2005). Job insecurity, extrinsic and intrinsic job satisfaction and affective organizational commitment of maintenance workers in parastatal. South African Journal of Business Management, 36(2), 27-39.

Carnevale, A. P., Smith, N., \& Strohl, J. (2013). Recovery: Job growth and education requirements through 2020.

Chang, S. and Lee, M. S. (2007), A study on the relationship among leadership, organizational culture, the operation of learning organization and employees" job satisfaction. Learning Organization, 14(02):155185

Chen, C. F. (2006). Job satisfaction, organizational commitment, and flight attendants' turnover intentions: A note. Journal of Air Transport Management, 12(5), 274-276.

Chiva, R., \& Alegre, J. (2008). Emotional intelligence and job satisfaction: the role of organizational learning capability. Personnel review, 37(6), 680-701.

Danish, R. Q., Draz, U., \& Ali, H. Y. (2015). Impact of Organizational Climate on Job Satisfaction and Organizational Commitment in Education Sector of Pakistan. American Journal of mobile Systems, Aplications and Service, 1(2), 102-109.

DeCenzo, D. A., \& Robbins, S. P. (1998). Supervision today. Pearson Education Inc: upper saddle River New Jersey, 7458, 173.

DeVaney, S. A., \& Chen, Z. (2003). Job satisfaction of recent graduates in financial services. Retrieved on, 12(12), 2006.

Derlina,, Aisyah,, Bukit, N., Sahyar,, Hassan, A., (2020). Blended Learning in English and English-Medium Physics Classes Using Augmented Reality, Edmodo, and Tinkercad Media. TESOL International Journal,15 (3), 111-136.

Egan, T. M., Yang, B., \& Bartlett, K. R. (2004). The effects of organizational learning culture and job satisfaction on motivation to transfer learning and turnover intention. Human Resource Development Quarterly, 15(3), 279-301.

Ellickson, M. C., \& Logsdon, K. (2001). Determinants of job satisfaction of municipal government employees. State and Local Government Review, 33(3), 173-184. 
Erdem, M., İlğan, A., \& Uçar, H. İ. (2014). Relationship between Learning Organization and Job Satisfaction of Primary School Teachers. International Online Journal of Educational Sciences, 6(1).

Gabris, G. T., \& Simo, G. (1995). Public sector motivation as an independent variable affecting career decisions. Public personnel management, 24(1), 33-51.

Gull, S., \& Azam, F. (2012). Impact of organizational culture type on job satisfaction level of employees' in different organizations of Lahore, Pakistan. International Journal of Academic Research in Business and Social Sciences, 2(12), 97.

Gunlu, E., Aksarayli, M., \&ŞahinPerçin, N. (2010). Job satisfaction and organizational commitment of hotel managers in Turkey. International Journal of Contemporary Hospitality Management, 22(5), 693-717.

Hassan, A., Mitchell, R., \& Buriro, H. A. (2020). Changes in uses of salutations in British English. International research journal of management, IT and social sciences, 7(1), 197204.https://doi.org/10.21744/irjmis.v7n1.840

Hassan, A., Kazi, A.S., Shafqat, A., Ahmed, Z., (2020). The Impact of Process Writing on the Language and Attitude of Pakistani English Learners. The Asian EFL Journal,27 (4.3), 260-277.

Hassan, A. K. (2020, January). Semantic Complications in the War on Terror Discourse and Manipulation of Language by State and Non-State Actors. International research journal of management, IT and social sciences, 7, 162-168. doi: https://doi.org/10.21744/irjmis.v7n1.838

Hassan, A., N. D.-e.-A. (2015). Language planning and language policy dilemma in Pakistan. International Journal of Linguistics, Literature and Culture (Linqua- LLC), 2, No 4.

Hassan, A. (2017, April 9). Is Paninian grammar a Dependency grammar? Why or why not? DIMENSION Journal of Humanities and Social Sciences.

Huang, H., Kvasny, L., Joshi, K. D., Trauth, E. M., \& Mahar, J. (2009, May). Synthesizing IT job skills identified in academic studies, practitioner publications and job ads. In Proceedings of the special interest group on management information system's 47th annual conference on Computer personnel research (pp. 121128). ACM.

Huczynski, A. \& Buchanan, D. (2010) OrganisationalBehaviour: An Introductory Text, 4th ed., Harlow: FT/Prentice Hall.

Itmeizeh, M., \& Hassan, A. (2020). New Approaches to Teaching Critical Thinking Skills through a New EFL Curriculum. International Journal of Psychosocial Rehabilitation, 24(07), 8864-8880.

Karabiyik, B., \&Korumaz, M. (2014). Relationship between teacher's self-efficacy perceptions and job satisfaction level. Procedia-Social and Behavioral Sciences, 116, 826-830.

Khan, A., \& Hassan, A., (2018, Feb). The Impact of Drug Abuse on Youth. DIMENSION Journal of Humanities and Social Sciences.

Khan, N., Aajiz, N. M., \& Ali, A. (2018). Comparison of Management Practices in Public and Private Universities in Khyber Pakhtunkhwa. Journal of Education and Educational Development, 5(1), 108-122.

Kreis, K., \&Brockopp, D. Y. (1986). Autonomy: A component of teacher job satisfaction. Education, 107(1).

Küskü, F. (2003). Employee satisfaction in higher education: the case of academic and administrative staff in Turkey. Career Development International, 8(7), 347-356.

Liao, H., \& Chuang, A. (2007). Transforming service employees and climate: a multilevel, multisource examination of transformational leadership in building long-term service relationships. Journal of applied psychology, 92(4), 1006.

Locke, E. A., \& Latham, G. P. (2002). Building a practically useful theory of goal setting and task motivation: A 35-year odyssey. American psychologist, 57(9), 705.

Lund, D. B. (2003). Organizational culture and job satisfaction. Journal of business \& industrial marketing, 18(3), 219-236.

Luthans, F., Avolio, B. J., Walumbwa, F. O., \& Li, W. (2005). The psychological capital of Chinese workers: Exploring the relationship with performance. Management and Organization Review, 1(2), 249-271.

Lyon, H. L., \&Ivancevich, J. M. (2000). An Exploratory Investigation of Organizational Climate and Job Satisfaction in a Hospital. Academy of Management Journal, 635-648.

Mahmoudi, H. M., \& Hassan, A. CHALLENGES AND ISSUES OF LANGUAGE USE BETWEEN MONOLINGUAL AND MULTILINGUAL SOCIETIES. Dimension Journal of Humanities and Social Sciences, 1-19.

Manel, M., Hassan, A., \& Buriro, H. A. (2019, March). Learners' Attitudes towards Teachers' switching to the mother tongue (The Case of Secondary school learners in Algeria). Indonesian Tesol Journal, 1(1), 9-26. 
Naderi Anari, N. (2012). Teachers: emotional intelligence, job satisfaction, and organizational commitment. Journal of workplace Learning, 24(4), 256-269.

Pasebani, F., Mohammadi, S., \& Yektatyar, M. (2012). The relationship between organizational learning culture and job satisfaction and internal service quality in sport organizations in Iran. Archives of Applied Science Research, 4(4), 1901-1905.

Quinn, R., Cameron, K., Degraff, J., \&Thakor, A. (2006). Competing values leadership: creating value in organizations. Northampton, MA: Edward Elgar Publishing Limited.

Rao,S.P.(2005) Essentials of HRM \& industrial Relationships,(480 to 482).

Rashid, S., \& Rashid, U. (2012). Work motivation differences between public and private sector. American International Journal of Social Science, 1(2), 24-33.

Ssesanga, K., \& Garrett, R. M. (2005). Job satisfaction of university academics: Perspectives

Seifollahi, Naseer; Davari, Muhammadreza (2008); Knowledge Management in Organizations; Tehran: Arad Ketab Publication

Sekaran, U. (1989). Paths to the job satisfaction of bank employees. Journal of organizational behavior, 10(4), 347-359.

Shurbagi, A. M. A., \& Zahari, I. B. (2012). The Relationship between Transformational Leadership, Job Satisfaction and the Effect of Organizational Culture in National Oil Corporation of Libya. In International Conference on Management, Applied and Social Sciences (ICMASS'2012) (pp. 24-25).

Silverthorne, C. (2004). The impact of organizational culture and person-organization fit on organizational commitment and job satisfaction in Taiwan. Leadership \& Organization Development Journal, 25(7), 592-599.

Šipilova, V. (2015). Education for Structural Change and Innovativeness of the Economy In Latvia. ProcediaSocial and Behavioral Sciences, 174, 1270-1277.

Sokoya, S. K. (2000). Personal predictors of job satisfaction for the public sector manager: implications for management practice and development in a developing economy. Journal of business in developing nations, 4(1), 40-53.

Spector, P. E. (1985). Measurement of human service staff satisfaction: Development of the Job Satisfaction Survey. American journal of community psychology, 13(6), 693-713.

Supriyatno, T., Susilawati, S., Hassan, A., (2020). E-learning development in improving students' critical thinking ability. Cypriot Journal of Educational Sciences, 15(5), 1099-1106. https://doi.org/10.18844/cjes.v15i5.5154

Us Saqlain, N., Shafqat, A., Hassan, A., (2020). Perception Analysis of English Language Teachers about Use of Contextualized Text for Teaching ESP. The Asian ESP Journal,16 (5.1), 275-299.

Volkwein, J. F., \&Parmley, K. (2000). Comparing administrative satisfaction in public and private universities. Research in Higher Education, 41(1), 95-116.

Yang, C. L., \& Hwang, M. (2014). Personality traits and simultaneous reciprocal influences between job performance and job satisfaction. Chinese Management Studies, 8(1), 6-26.

Yasmeen, S., Alam, M. T., Mushtaq, M., \& Bukhari, M. A., (2015). Comparative study of the availability and use of information technology in the subject of education Public and Private Universities of Islamabad and Rawalpindi. SAGE Open, 5(4), 2158244015608228. 